\title{
EXPERIMENTAL USE OF A MARKET-BASED APPROACH TO THE EFFICIENT ALLOCATION OF RESOURCES WITHIN THE GOVERNMENT BUDGET
}

\section{Vladimír Štípek*}

\begin{abstract}
The aim of this article is to test the possibility of a more efficient allocation of resources using market tools when proposing the government budget. The tool is the distribution of ownership rights when designing individual chapters of the budget at the specific stage of the government budget finalisation. The assumption is that the exchange of ownership rights between the individual chapters would lead to a more efficient allocation of resources than mere negotiation. The precondition is the correct setting for such negotiation. For this reason, the article uses an economic experiment in which three budget chapters of expenditure (industry, education, transport) can exchange ownership rights with allocated funds for the following areas: salary expenditure, investment, current expenditure. The design of the experiment is based on a review of relevant studies and literature; illustrative data used in the experiment correspond to the current reality. The article shows these innovative possibilities based on the conducted experiments where the roles were divided between the group of participants representing the individual ministries while the needs and possibilities of the ministries to exchange resources were defined within a set framework of the experiment rules and using the government budget of the Czech Republic for 2020 as the example. The article also implies the possible applications of this method. This method is generally applicable under the proper method design.
\end{abstract}

Keywords: market-based approach, government budget, distribution of ownership rights JEL Classification: H61, C91, C92

\section{Introduction}

This article responds to the implicit problem pertaining to public budgets: a constant increase in expenditure, e.g. due to the need to finance newly emerging programmes, without the existing ones being cut. The inability to cut the existing programmes stems from the information asymmetry and corresponds to the natural behaviour of the bureaucratic apparatus.

The proposed method of using the market allocation of resources within the government budget should partially solve this problem under certain conditions outlined in the economic experiment.

* Metropolitan University Prague, Department of International Business (vladimir.stipek@mup.cz). 
The mentioned use of market principles conforms to a simple rule: the funds are divided among all the players involved (in terms of the Czech budget, the budget chapters) according to basic categories: operational expenditures, salary expenditures, investment expenditures (i.e. acquisition expenditures).

In these categories, the actors will be able to make exchanges among themselves in a 1:1 ratio, thus ensuring a more efficient allocation of funds. During the distribution, the actors will be given a certain right of ownership allowing them to decide, at their own discretion, whether to retain the entrusted funds or to exchange them.

Furthermore, on the basis of the practical example of the budget draft of the Czech Republic for 2020, this article aims to simulate a new form of decision-making regarding additional budgetary resources using market principles. This article uses a wide range of data, which is presented in more detail in the next chapter.

\section{Literature Review}

From the point of view of literature and other information sources, the article can be divided into several parts:

a. This was primarily inspired by the innovative market-based approach used by NASA (Wessen and Porter, 1998). All other sources used are mentioned in the text.

b. The innovative approach consisting in the distribution of ownership rights to inputs for more efficient allocation was applied to the problem arising from the existing bureaucratic barriers - information asymmetry and bureaucracy interests lead to the inefficient distribution of budgetary resources. The theory of bureaucracy and later approaches to this theory that characterises decisionmaking limits within the bureaucratic structure are of key importance to this article.

c. The preparation of the budget is governed by a complex of standards or other binding documents that regulate procedures and parameters. These include, for example, the procedures laid down in the Budget Rules Act (MFCR, 2000), as well as the Accounting Act (MFCR, 1991). These laws set out the roles, specific procedures and sources of information for the preparation of the budget. The parameters are then set out in the Medium-Term Outlook for the Government Budget, the Macroeconomic Forecast of the Ministry of Finance (MFCR, 2018a), the EU Multiannual Financial Framework (EC, 2018), etc., with the decisive features provided by the closing account of the state budget for the year (MFCR, 2018b). This article assumes that an important conditioning factor is the composition and efficiency of public expenditure (Szarovská, 2016). The idea of the importance of a proper structure of public finances determines the aim of this article - increasing the real efficiency of the distribution of budget resources can help the overall efficiency of public finances and the whole economy.

d. This article (the experimental part) is based on an experimental approach to economics, as also used by Veron Smith (1994). When applying the experimental method, it is necessary to define the environment, characteristics and roles of the players in the experiments, as well as the tools available to the players. 
The key is the distribution of roles, where the players have to follow the instructions in the role, while maintaining a certain field of action. This field helps to bring the players' behaviour closer to real players of the economic policy. The roles and framework of the game, together with an appropriate design of the experiment, can help avoid irrational behaviour. The motivations of the experiment participants can be different, based on psychological predispositions and other circumstances (Smith, 1991). Psychology opens up a number of further motivations that can affect the view of the experiment participants. However, an appropriate design of the experiment framework can reduce, if not eliminate, the risks. Therefore, the psychological approach that opens up the possibilities to relativise the motivations of the experiment participants is not optimal, but it enables us to set the roles in a way that reduces the methodology's weaknesses.

$\boldsymbol{e}$. Data sources are based on budgetary reports and parliamentary documents. The design of the experiment is based on the real levels of the financial resources of budgetary chapters - experiment input data corresponds to the current reality.

\section{Experiment Methodology}

Two methods are used in the article - the descriptive method and the method of economic experimentation. The descriptive method refers to the specifications of the government budget of the Czech Republic. The second method, economic experimentation, will test the form of negotiations on the exchange of funds within the basic categories taking place between the players.

The theoretical basis for the experiment is the market-based approach used in the development and preparation of the Cassini probe to Saturn. Organisers from NASA distributed between the teams the ownership rights to key characteristics such as weight, volume, mass, energy performance. Then, the teams were able to exchange these ownership rights at a particular rate according to their needs. If one of the teams did not need the total volume originally allocated for their part of the probe, it could exchange the rest with another team, e.g. for weight. As a result, the entire probe could turn out to be lighter or smaller, i.e. resources for the preparation of the probe were distributed effectively. At the beginning of the work on the development of the probe's individual components, none of the actors knew how to effectively allocate these characteristics, although it was found how to do so in the course of development and exchange (Wessen and Porter, 1998).

However, this idea needs to be combined with approaches that take into account the negotiation system. These primarily include game theory or variations of the prisoner's dilemma, from the point of view of this article, as a way of negotiating, when motives do not have only one goal, but a combination of goals in situations of imperfect information or hidden limits of the decision-making. The experiment is thus based on some characteristics of the traditional perception of game theory (Nash, 1951; 1953), but also on the derivatives of this concept (Rusciano, 1990). Individual negotiating actors can have different roles - they can play a non-cooperative game where they do not reveal all information and motivation, or they can play a turn-by-turn cooperative game, where each turn is their best possible outcome in a given situation and under the given conditions. The forms of cooperation made available to the actors are then governed by setting the budgetary parameters or the framework of the experiment. 
Behind the experiment, the article contains a subchapter dealing with the possibilities of application in the real conditions of the actual government budget (chapter 5). This application should validate the framework in which the method could be used.

As mentioned, the budgeting process is based on the budget parameters from the previous year, which are replaced by known variables. The prepared budget can then be compared with the final approved budget and the difference is comprised of the means, for which individual chapters compete. An example of this is the government budget for 2020. A suitable moment for application of the new method to increase the efficiency of the distribution of resources within the budget can be identified on the basis of two prepared versions of the budget - the medium-term outlook for the state budget for 2020 and the version that reflects its actual amount (after the government's approval). It is the differences between these two versions that elucidate the room for improving the efficiency of resource allocation within the budget.

Experiment results can be used for increasing the transparency of public finances. In the budget documentation, it is possible to publish details from the negotiations between budget chapters. It is a transparent way of how to avoid unfair bargaining under this method are all the processes described and there is a defined "exchange rate" (1:1) of different kinds of resources. Open budget preparation allows public control and this method should be a contribution to compliance with IMF`s Fiscal Transparency Code (IMF, 2019).

\section{Budgeting Description}

The process of budgeting at the level of central government, as exemplified in this article using the state budget of the Czech Republic, is a complex annual procedure which, from the first proposals, through negotiations and adjustments to the final approval, took almost the whole of the previous year. This process has many stages with many parties and institutions involved.

However, some stages of budget preparation are not based on expert analyses or expert settings, but solely on negotiation. This makes these phases more similar to game theory, where the subjects must build their tactics around the clear aim of maximising their own budget regardless of efficiency. In general, so-called information asymmetry is at play here, as a classic reason for inefficient management of public finances. The individual stages of a given organisational unit do not provide the necessary information to the superior units (Löfgren, Persson and Weibull, 2002). What motivates them to such behaviour are their own interests, e.g. to maintain the amount of their budget, the extensiveness of the agenda, the number of employees, etc. Thus, due to specific information and the monopoly on such information, members of the bureaucracy can manipulate, for example, the politicians who decide on the form of bureaucracy (Bendor, Taylor and Van Gaalen, 1987).

Budgeting, i.e. the distribution of expected tax and other revenues among individual budget chapters, is an annual activity that has its methodology, but at the same time, part of the resources are allocated on the basis of negotiation and political compromise. There are a number of principles on how to proceed to the distribution of financial resources. A precept of fair process is generally accepted.

Budgeting is an activity at the national level (i.e. NUTS 2 level within the EU), which has a number of phases; in the conditions of the Czech Republic, the preparation process 
is almost one year long and is affected by many factors. Continuity with the previous budget and takeover of the previous year's data are an important factor, as the situation is relatively stable, and inertia is present in a number of budget items. To simplify, the preparation of the budget is based on the previous years, where the requirements of the creators of individual budget parts are incorporated. Thus, the budget is not a result of the market pressures, it does not settle into equilibrium, as does, e.g. market equilibrium price, market salary, etc. Individual budget makers do not compete with each other on the basis of market elements, it is only their bargaining power, items from past budgets, etc., that matter.

Overall, the budget structure (the composition of expenditure, in other words) has an impact on effectiveness and economic growth, although it is almost impossible to distinguish the real impact of public investment and spending. However, as Barrios and Schaechter (2008) suggest, empirical studies have nevertheless identified certain types of expenditure that have been associated with higher growth. This article presents a method which is able to appoint the productive use of resources by using organised negotiation rather than any analytical method. Other possible methods are finding efficiency in counting the value-added of education spending, transport spending etc. or other measures. These typical analytical methods are based on subjective evaluation or multiplier effects. This article proposes a method which can bring market pressure into the budget decision-making process. "Public finance has both normative and positive elements and moving between theory and practice requires attention to help us understand which policies the government should adopt and whether it is likely to do so. We should not be surprised when bad policies are adopted in spite of better policies being available if our political system is structured to deliver bad outcomes" (Auerbach, 2009, p. 1). In spite of this omnipresent inability to distinguish the correct budget policy, the proposed method of this article offers a guide on how to allocate resources without subjective analytical considerations - the method represents utilizing market power.

"Considerations of justice require that the processes through which decisions are arrived at embody principles that are deemed fair, and where, for example, all relevant stakeholders have access to information and the possibility to affect decisions that impact them" (Lakin, and de Renzio, 2019, p. 5). In the method presented in this article, stakeholders are involved in the decision-making process.

Nevertheless, market elements can be applied to certain budgeting stages and parts of the budget. Typically, this could be the distribution of additional funds that appear during budget preparation (e.g. a change in the predicted economic growth with an impact on the estimated tax revenue). Thus, the allocation of additional funds does not have to be strictly guided by the budgeting mechanisms, as a number of preparation stages have already taken place and only a change in some parameters should be made. The subsequent approval of the budget, thus amended, is a routine approval of the government budget bill. However, changes made to the budget from a certain stage of preparation do not have to be guided by efforts to meet the necessary needs based on laws and practical needs. Additional funds (e.g. additional tax revenue, which is not used, e.g. to reduce debt or to replenish the reserves) are distributed exclusively based on the negotiating capabilities and subjective feelings about the importance of the given expenditure program.

The following experiment uses hypothetically appropriate moments for the application of an instrument that differs from the usual negotiation of the representatives of budget 
chapters and enables decisions to be made based on market pressures. After the experimental verification of the capabilities of this method, the capabilities are illustrated on the basis of the real budget for 2020, where two stages of budgeting are selected, and their differences also demonstrate room for application.

\section{Economic Experiment}

An economic experiment as a scientific method can be used in situations where we want to verify in practice a new procedure or a practical method or theory, not just to verify the existence of a particular phenomenon for which we have hard data. Of course, an economic experiment can also be used to verify the existence of a phenomenon, but in economics, specifically in economic policy, where the impact of national economic measures needs to be estimated, the economic experiment is a very welcome tool for determining the impact. Experiments can simulate all sorts of factors that we want to translate into measures that we consider essential. This means that the system settings can be combined, and the behaviour of measures can be simulated under the influence of certain factors.

The basis of the experiment to estimate the possibility of the application is goal definition. In this case, the goal can be defined as verification of the theoretical concept of the use of market principles in a specific non-market environment of decision-making on the government budget. The theoretical basis is whether and how this approach will help allocate resources more efficiently. The experiment should thus simulate the application of this approach to the budget and evaluate the state after the experiment is conducted.

The principles of the experiment are as follows: In the group of experiment participants, roles are distributed according to the main budget chapters, where the use of funds on basic purposes, which are salary expenditures, investment expenditures, operating expenditures or acquisition expenditures, can be identified. There is a wide range of forms of experiments, which are, however, dominated by forms that seek equilibrium in the area of price, where buyers and sellers trade with each other (Plott and Smith, 1978). Individual chapters will be given the option to exchange resources between several basic purposes/ categories, such as labour costs, operating costs, investment costs (acquisition costs).

The basic groups of participants will be given imaginary ownership rights (right to exchange with other groups) to the funds entrusted. The essence of these ownership rights is the option to exchange the original allocation of funds on salaries/investment expenditures/operating expenditures between chapters in order to achieve a more efficient allocation according to the set exchange rate - how much of the funds from one chapter can be exchanged for funds in another chapter (of course, resources cannot be exchanged within their own chapter) ${ }^{1}$, although a ratio of $1: 1$ is offered in the field of financial expression.

1 A mere exchange of funds between different types of expenditure within one chapter is not rational, as there is a lack of strong incentive to gain funds on a priority item and cut down expenditures on less prioritised items - without external influence, which is represented here by the need to exchange with other chapters, in the "Minister's" thought process, might ensure the status quo for their chapter, which is the case in reality, where no reduction in less prioritised items takes place and new resources for priorities are sought instead. 


\subsection{Design of the Experiment}

The participants in the experiment were divided into three groups, each representing one of the following ministries: industry, education and transport. Each ministry was allocated the same funds in the amount of 600 million CZK, always in three basic expenditure areas: salaries, investments and current expenditures. These ministries were selected on the basis that their main budget demands lie in these three expenditure areas. Due to a large number of teachers, the education sector is demanding with regard to salaries, while the transport sector needs sufficient investment resources and the industry sector has relatively significant current expenditures if we consider support for various forms of business, such as SMEs, or export support. In view of this experiment, these expenditures constitute a number of smaller current expenses, such as small subsidy programmes, support and service for SMEs, export missions, participation in trade fairs etc.

Within each team, a representative was appointed "Minister", while the rest of the team consisted of "Deputies". An example is the following sequence of exchanges between the Ministry of Defence and Culture. It is clear that the Ministry of Defence is dominated by salary expenditures, while the Ministry of Culture spends the most on investing (in a new library). This means that the distributed funds do not cover all funds for salaries of the Ministry of Defence (the need for an additional 100 million CZK), but the Ministry needs fewer current expenditures (security costs) than the basic subsidy of 200 million CZK, so it can exchange 100 million CZK. The Ministry of Culture, on the other hand, does not have enough funds for investments (it needs 250 million CZK) and has a surplus of salary funds for supporting the so-called living culture.

Description of individual sequences: The Ministry of Defence identifies the need for 100 million CZK for salaries $(\boldsymbol{A})$ and the current expenditure surplus of 100 million CZK $(\boldsymbol{B})$. It is not possible to transfer funds between these needs within the chapter. Therefore, the Ministry of Defence will contact the Ministry of Culture, which identified the need for 250 million CZK for investments $(\boldsymbol{C})$ and which also has a surplus of 150 million CZK in salaries $(\boldsymbol{D})$. The Ministry of Defence will, therefore, agree to receive 100 million CZK $(\boldsymbol{E})$ from the Ministry of Culture for salaries from its salary funds $(\boldsymbol{F})$. Another agreement will be to exchange surplus security costs of 100 million CZK $(\boldsymbol{G})$ with the Ministry of Culture, which needs 250 million CZK, although the available funds are only 100 million CZK so that the Ministry of Culture receives only 100 million CZK $(\boldsymbol{H})$.

Table 1 | Sample for experiment

\begin{tabular}{|l|c|c|c|c|l|}
\hline Ministry of Defence & $\begin{array}{c}\text { Distribution } \\
\text { (mil CZK) }\end{array}$ & $\begin{array}{c}\text { What you } \\
\text { need }\end{array}$ & $\begin{array}{c}\text { Free/ } \\
\text { blocked } \\
\text { money }\end{array}$ & $\begin{array}{c}\text { What you } \\
\text { got/gave } \\
\text { over? }\end{array}$ & $\begin{array}{c}\text { Who is your } \\
\text { partner }\end{array}$ \\
\hline $\begin{array}{l}\text { Labour - soldiers } \\
\text { salary increase }\end{array}$ & 200 & 300 & $A-100$ & $E+100$ & $\begin{array}{l}\text { Culture } \\
\text { (Labour) }\end{array}$ \\
\hline $\begin{array}{l}\text { Investment - new } \\
\text { combat vehicles }\end{array}$ & 200 & 200 & 0 & & \\
\hline $\begin{array}{l}\text { Costs - security } \\
\text { expenditures }\end{array}$ & 200 & 100 & B 100 & G -100 & $\begin{array}{l}\text { Culture } \\
\text { (Investment) }\end{array}$ \\
\hline Total & 600 & 600 & & & \\
\cline { 1 - 4 }
\end{tabular}




\begin{tabular}{|c|c|c|c|c|c|}
\hline Ministry of Culture & $\begin{array}{l}\text { Distribution } \\
\text { (mil CZK) }\end{array}$ & $\begin{array}{l}\text { What you } \\
\text { need }\end{array}$ & $\begin{array}{l}\text { Freel } \\
\text { blocked } \\
\text { money }\end{array}$ & $\begin{array}{c}\text { What you } \\
\text { got/gave } \\
\text { over? }\end{array}$ & $\begin{array}{l}\text { Who is your } \\
\text { partner }\end{array}$ \\
\hline Investment - new library & 200 & 450 & $C-250$ & $\boldsymbol{H}+100$ & $\begin{array}{l}\text { Defence } \\
\text { (Costs) }\end{array}$ \\
\hline $\begin{array}{l}\text { Costs - reconstruction } \\
\text { of castles }\end{array}$ & 200 & 100 & 100 & & \\
\hline Labour - live culture & 200 & 50 & D 150 & $F-100$ & $\begin{array}{l}\text { Defence } \\
\text { (Labour) }\end{array}$ \\
\hline Total & 600 & 600 & & & \\
\hline
\end{tabular}

Source: Author's own processing

\subsection{Experiment Results}

The following tables show the results of the first implementation of the experiment (carried out on November 20, 2019; November 27, 2019; December 14, 2019), specifically on behalf of a group of experiment participants representing the Ministry of Education (8 participants; not recorded; 3); (5 participants; 6; 8), Ministry of Transport (8 participants; 5; 6).

The distribution of funds was even across all groups; the needs totalled 600 million CZK. The specific distribution of needs that can be satisfied within the allocated resources is not even in order to reinforce the different motivation of the ministry in question to make the exchange.

The Ministry of Education needed 200 million CZK, received 150 million CZK from the Ministry of Industry (50 million CZK) and Transport (100 million CZK). Vice versa, it provided the Ministry of Industry with an excess of 50 million CZK from current expenditures and provided the Ministry of Transport with 100 million CZK from investment funds. The Ministry of Industry needed 100 million CZK for current expenditures and received it from the Ministry of Education and Ministry of Transport.

\section{Table 2 | First experiment}

\begin{tabular}{|l|c|c|c|c|c|}
\hline Ministry of Education & $\begin{array}{c}\text { Distribution } \\
\text { (mil CZK) }\end{array}$ & $\begin{array}{c}\text { What you } \\
\text { need }\end{array}$ & $\begin{array}{c}\text { Free/ } \\
\text { blocked } \\
\text { money }\end{array}$ & $\begin{array}{c}\text { What you } \\
\text { got/gave? }\end{array}$ & $\begin{array}{c}\text { Who is your } \\
\text { partner? }\end{array}$ \\
\hline $\begin{array}{l}\text { Labour - teachers } \\
\text { salary increase }\end{array}$ & 200 & 400 & -200 & $+50,+100$ & $\begin{array}{l}50 \\
\text { industry, } \\
100 \\
\text { transport }\end{array}$ \\
\hline $\begin{array}{l}\text { Costs - increasing } \\
\text { prices of energy }\end{array}$ & 200 & 150 & 50 & -50 & industry \\
\hline $\begin{array}{l}\text { Investment }- \\
\text { IT equipment }\end{array}$ & 200 & 50 & 150 & -100 & transport \\
\hline Total & 600 & 600 & & &
\end{tabular}




\begin{tabular}{|l|c|c|c|c|l|}
\hline Ministry of Industry & $\begin{array}{c}\text { Distribution } \\
\text { (mil CZK) }\end{array}$ & $\begin{array}{c}\text { What you } \\
\text { need }\end{array}$ & $\begin{array}{c}\text { Free/ } \\
\text { blocked } \\
\text { money }\end{array}$ & $\begin{array}{c}\text { What you } \\
\text { got/gave? }\end{array}$ & $\begin{array}{c}\text { Who is your } \\
\text { partner? }\end{array}$ \\
\hline $\begin{array}{l}\text { Costs - support } \\
\text { for export }\end{array}$ & 200 & 300 & -100 & $+50,+50$ & $\begin{array}{l}\text { education, } \\
\text { transport }\end{array}$ \\
\hline $\begin{array}{l}\text { Investment } \\
-- \text { support } \\
\text { for investment } \\
\text { in enterprises }\end{array}$ & 200 & 150 & 50 & -50 & transport \\
\hline $\begin{array}{l}\text { Labour - salaries } \\
\text { of employees } \\
\text { (economic } \\
\text { diplomacy) }\end{array}$ & 200 & 150 & 50 & -50 & education \\
\hline Total & 600 & 600 & & & \\
\hline
\end{tabular}

\begin{tabular}{|c|c|c|c|c|c|}
\hline Ministry of Transport & Distribution & $\begin{array}{l}\text { What you } \\
\text { need }\end{array}$ & $\begin{array}{l}\text { Freel } \\
\text { blocked } \\
\text { money }\end{array}$ & $\begin{array}{l}\text { What you } \\
\text { got/gave? }\end{array}$ & $\begin{array}{c}\text { Who is your } \\
\text { partner? }\end{array}$ \\
\hline $\begin{array}{l}\text { Investment - } \\
\text { investment into } \\
\text { regional roads }\end{array}$ & 200 & 400 & -200 & $+100,+50$ & $\begin{array}{l}\text { education, } \\
\text { industry }\end{array}$ \\
\hline $\begin{array}{l}\text { Labour - salaries } \\
\text { of professionals } \\
\text { of EU funds }\end{array}$ & 200 & 100 & 100 & -100 & \\
\hline $\begin{array}{l}\text { Costs - external } \\
\text { analyses }\end{array}$ & 200 & 100 & 100 & -50 & \\
\hline Total & 600 & 600 & & & \\
\hline
\end{tabular}

Source: Author's own research

The recommendation may not be to limit the efficiency of the allocation by an equable balance - if the balance is well-balanced (and at the same time with partial imbalances at various types of costs), this imbalance will be reflected in the negotiations. If they were well-balanced (note: this experiment did not use equable balance), the optimal allocation might not be achieved if affected by the complexity of the negotiations (imperfect information, the difficulty of finding a partnership chapter for exchange). If the requirements are lower than the available resources, then the efficiency in terms of profits of individual budget chapters will be higher. However, if we perceive efficiency as an unknown equilibrium that can only arise through interaction and negotiation, then any setting that provides negotiation space is appropriate. Failure to satisfy all budgetary requirements, or vice versa, the excess of unallocated funds (beyond the defined necessary expenditure) points to a potential equilibrium, just like the market price (which is de facto formed in the same way) is an equilibrium of sorts. 


\section{Discussion of Conditions for Application in the Government Budget for 2020}

The experimental verification of the possibility of using the market allocation of resources within the government budget implies the conclusion that the application of this approach is possible. However, a necessary condition is a suitable situation where there is no other method of distribution or another method of distribution is considered to be an unsuitable method for which an alternative can be used.

\section{Table 3 | Budget chapters}

\begin{tabular}{|c|c|c|c|}
\hline Budget chapter & $\begin{array}{l}2020 \text { plan from } \\
\text { the medium-term } \\
\text { outlook }(2018)\end{array}$ & $\begin{array}{l}2020 \text { expenditures } \\
\text { from the version } \\
\text { for the Chamber } \\
\text { of Deputies } \\
\text { of the Parliament }\end{array}$ & $\begin{array}{c}\text { Change } \\
\text { in } \%\end{array}$ \\
\hline Total (all budget chapters) & 1471296931140 & 1618118723753 & 9,98 \\
\hline Ministry of Labour & 653857219582 & 686800038058 & 5,04 \\
\hline Ministry of Education & 200257665976 & 226467000210 & 13,09 \\
\hline General treasury administration & 173328681429 & 163150951475 & $-5,87$ \\
\hline Ministry of Defence & 76280513750 & 75500365700 & $-1,02$ \\
\hline Ministry of Interior & 76240877087 & 81519358975 & 6,92 \\
\hline Ministry of Transport & 49110345323 & 67972681089 & 38,41 \\
\hline Government Budget Administration & 48384000000 & 43810880286 & $-9,45$ \\
\hline Ministry of Industry & 38352323056 & 49704100259 & 29,60 \\
\hline Ministry of Justice & 31285023314 & 31891409426 & 1,94 \\
\hline Ministry of Agriculture & 23876215333 & 56544982069 & 136,83 \\
\hline Ministry of Finance & 23182199324 & 23889153719 & 3,05 \\
\hline Ministry of Culture & 14482652702 & 15249131176 & 5,29 \\
\hline Ministry of Environment & 8616094143 & 15899438896 & 84,53 \\
\hline Foreign Office & 8087070530 & 8171302949 & 1,04 \\
\hline Ministry of Health & 7475612471 & 9250443374 & 23,74 \\
\hline Czech Academy of Science & 6196493000 & 6513390450 & 5,11 \\
\hline
\end{tabular}

Source: Author's own processing using data from MFCR (2018c), CDP (2019).

The overview in table 3 shows the changes between 2018, when the government budget outlook for 2020 (MFCR, 2018c) was published, and 2019, when the 2020 budget version was prepared (CDP, 2019). Chapters with a budget of over 5 billion CZK were included in the overview below. It is clear that the overall budget increased by almost $10 \%$ compared to the preliminary plan in the medium term. We can identify different reasons for changes to the individual chapters; the more significant reasons often include transferring agendas that the ministry has to implement, the need to co-finance programmes, etc. However, at some stages of budget preparation, the arguments are soft and depend only on the negotiating position of the ministers. In addition, the negotiation 
always involves additional funds, not a revision of the funds already allocated. Negotiations are often motivated by gaining additional resources, regardless of their effectiveness. This is where the laws of the bureaucracy theory appear, which do not adequately emphasise the possible reduction of less efficient expenditures or the so-called trade-off between various other spending programmes.

The table shows that there is room for redistribution within the chapter - between the budget outlook and the government-approved budget adopted by the Chamber of Deputies for approval, there was an approximate 10\% increase of 146.8 billion CZK. For some chapters, the budget was reduced compared to the outlook, while for others it was increased - this is the case for all three experimentally examined chapters (transport, education and industry expenditure). A practical demonstration can illustrate the possibilities for negotiation and application of the experimental method. The result cannot be ascertained, but the theoretical assumptions for conducting the experiment can be demonstrated on a practical example of the 2020 budget.

For all three chapters, the appropriations for current expenditure are given below, as well as salaries and investment expenditure. The difference and the change between the outlook and the budgeted expenditure show the possibilities for introducing a new method $-\boldsymbol{a}$. in the form of greater needs that were actually met under the 2020 budget (i.e. to incorporate such needs into the possible application of the method); $\boldsymbol{b}$. in terms of possible exchanges of funds, it is clear that the difference in needs between the outlook and the budget shows the potential space that may be sacrificed in the chapters and at the expense of which other expenditure may be prioritised (e.g. the chapter may sacrifice salaries in exchange of funds for investment), as the first draft budget in the form of an outlook is already a relevant outline in the Czech Republic, which could also serve as a provisional budget.

The table below shows the needs/potential free resources (within current expenditure which comprises labour costs) for the education sector, which increased by $13 \%$ during finalisation, for transport by more than $7 \%$ and for industry by more than $3 \%$. It is assumed that the education sector has the greatest needs in the salary area.

Table 4 | Space for redistribution of money within current expenditure

\begin{tabular}{|l|c|c|c|c|}
\hline Current expenditure & $\begin{array}{c}\mathbf{2 0 2 0} \text { outlook } \\
\text { (CZK billion) }\end{array}$ & $\begin{array}{c}\mathbf{2 0 2 0} \text { budget } \\
\text { (CZK billion) }\end{array}$ & $\begin{array}{c}\text { Difference } \\
\text { in CZK billion }\end{array}$ & Difference in \% \\
\hline Ministry of Education & 193,839 & 219,569 & 25,730 & 13,3 \\
\hline Ministry of Transport & 19,005 & 20,353 & 1,348 & 7,1 \\
\hline Ministry of Industry & 37,063 & 38,230 & 1,167 & 3,1 \\
\hline
\end{tabular}

Source: Author’s own processing using data from MFCR (2018c), CDP (2019).

Capital expenditure is most pronounced in the case of the Ministry of Transport. In the case of the Ministry of Industry and Trade, the value of capital expenditures in the outlook was inadequately low (1.29 billion CZK - an increase to budgeted expenditures of 11.47 billion CZK would represent growth of more than $700 \%$ ), which is not in line with the reality of previous budgets. Therefore, the closest possible actual value of planned expenditures was used, i.e. that of 2019. 
Table 5 | Space for redistribution of money within capital expenditure

\begin{tabular}{|l|c|c|c|c|}
\hline Capital expenditure & $\begin{array}{c}\text { 2020 outlook } \\
\text { (CZK billion) }\end{array}$ & $\begin{array}{c}\text { 2020 budget } \\
\text { (CZK billion) }\end{array}$ & $\begin{array}{c}\text { Difference } \\
\text { in CZK billion }\end{array}$ & Difference in \% \\
\hline Ministry of Education & 6.419 & 6.898 & 0.479 & 7.5 \\
\hline Ministry of Transport & 30.105 & 47.620 & 17.514 & 58.2 \\
\hline Ministry of Industry* & 4.157 & 11.474 & 7.317 & 176.0 \\
\hline
\end{tabular}

Source: Author's own processing using data from MFCR (2018c), CDP (2019).

* In the case of the Ministry of Industry and Trade, we did not use the investment expenditure from the outlook but the budgetary reality of 2019.

In nominal terms, salary expenditures are the most significant in the case of the education sector. In other ministries, they are considerably less (approx. 1 billion $\mathrm{CZK}$ ), although there is also a definite increase and chapters probably have room for possible negotiations.

Table 6 | Space for redistribution of money within salary expenditure

\begin{tabular}{|l|c|c|c|c|}
\hline \multicolumn{1}{|c|}{ Salary expenditure } & $\begin{array}{c}\mathbf{2 0 2 0} \text { outlook } \\
\text { (CZK billion) }\end{array}$ & $\begin{array}{c}\mathbf{2 0 2 0} \text { budget } \\
\text { (CZK billion) }\end{array}$ & $\begin{array}{c}\text { Difference } \\
\text { in CZK billion }\end{array}$ & Difference in \% \\
\hline Ministry of Education & 101.070 & 111.536 & 10.466 & 10.4 \\
\hline Ministry of Transport & 0.515 & 0.580 & 0.065 & 12.6 \\
\hline Ministry of Industry & 0.996 & 1.255 & 0.259 & 26.0 \\
\hline
\end{tabular}

Source: Author's own processing using data from MFCR (2018c), CDP (2019).

\section{Conclusion}

The article shows how an innovative method of the distribution of ownership rights and subsequent exchanges could be used in practice to increase the efficiency of resource allocation within budgetary policy. The method was tested in an experiment conducted, for the purpose of this article, on the real data of the government budget of the Czech Republic for 2020, where space was identified in which the method could be used.

It is necessary to describe in detail the method of distribution of resources by means of market instruments and to explain the situation and conditions under which it can be applied. Therefore, the article examines in detail the framework and methodology of the experiment conducted. The method is applicable under predefined conditions in the case of the budget, negotiations can only be used after the first draft has been prepared, which could already serve as the budget itself and satisfy all the necessary budgetary needs imposed by law or other economic policy requirements. This approach is applicable to any economy - of course, based on specific conditions. This article shows two examples of application: the government budget of the Czech Republic based on an experiment and previous real use in NASA.

Experimental testing shows the possibility of using the method in practice. Negotiation results based on the distribution of ownership rights associated with the possibility of negotiation can be seen as a more efficient allocation than a distribution based on mere 
negotiation. The key is the need to sacrifice part of the funds in order to raise other funds. This will reduce budget requirements or at least better distribute these funds. Negotiation set up in this way does not suffer from the traditional problem of bureaucracy. i.e. the problem of constantly increasing the budget without motivation while keeping the allocated funds regardless of their efficiency. The market motive provides the possibility (from the point of view of the chapter in question) to dispose of less effective funds in favour of other more efficient resources. It should be noted that the chapter can use information asymmetry, as the budget maker does not have internal information on the effectiveness of the funds in the chapter.

The article should demonstrate, as inspired by NASA practice, the possibility of using market motives in the distribution of resources in a specific environment of the government budget. This article identifies the space for utilisation and the conditions and limits of use of these methods, which should lead to greater efficiency of resource allocation among the government budget chapters.

\section{References}

Auerbach, A.J. (2009). Public Finance in Practice and Theory [online]. International Institute of Public Finance (IIPF) - Center for Economic Studies (CES) at LMU Munich. Available at: https://www.iipf.org/rmvp08_auerbach.pdf [Accessed 20 Apr. 2019]

Barrios, S., and Schaechter, A. (2008). The Quality of Public Finances and Economic Growth [online]. Economic papers 337. Available at: https://ec.europa.eu/economy_finance/ publications/pages/publication13101_en.pdf [Accessed 3 Jul. 2019]

Bendor, J., Taylor, S., and Van Gaalen, R. (1987). Politicians, Bureaucrats, and Asymmetric Information. American Journal of Political Science, 31(4), pp. 796-828.

https://doi.org/10.2307/2111225

MFCR (Ministry of Finance of the Czech Republic), (1991). Act No. 563/1991 Coll., on Accounting. List of Acts, as amended - in valid wording [online]. Noveaspi.cz. Available at: https://www.noveaspi.cz/products/lawText/1/39611/1/2 [Accessed 25 Sep. 2019]

MFCR (2000). Act No. 218/2000 Coll., on Budget Rules. List of Acts, as amended - in valid wording [online]. Noveaspi.cz. Available at: https://www.noveaspi.cz/products/ lawText/1/49515/1/2 [Accessed 25 Sep. 2019]

MFCR (2018a). Macroeconomic Forecast of the Ministry of Finance - April 2018 [online]. Mfcr.cz. Available at: https://www.mfcr.cz/cs/verejny-sektor/makroekonomika/makroekonomickapredikce/2018/makroekonomicka-predikce-duben-2018-31528 [Accessed 3 Jul. 2019]

MFCR (2018b). Closing Account of the Government Budget for 2018 [online]. Mfcr.cz. Available at: https://www.mfcr.cz/cs/verejny-sektor/statni-rozpocet/plneni-statniho-rozpoctu/2018/ statni-zaverecny-ucet-za-rok-2018-36452 [Accessed 3 Jul. 2019]

MFCR (2018c). Medium-Term Outlook for the Government Budget of the Czech Republic for the Years 2020 and 2021, E. Table section [online]. Psp.cz. Available at:

https://www.psp.cz/sqw/text/tiskt.sqw?O $=8 \& C T=288 \& C T 1=0$ [Accessed 3 Jul. 2019]

EC (European Commission), (2018). Multiannual Financial Framework for the Years 2014-2020,

Council Regulation No 1311/2013 [online]. Eur-lex.europa.eu. Available at:

https://eur-lex.europa.eu/legal-content/cs/TXT/PDF/?uri=CELEX:32013R1311\&from=EN

[Accessed 14 Jun. 2019]

CDP (Chamber of Deputies of the Parliament), (2019). Parliamentary Print 605, Government Bill on the Government Budget of the Czech Republic for 2020 [online]. Psp.cz. Available at: http://www.psp.cz/sqw/text/tiskt.sqw?O $=8 \& C T=605 \& C T 1=0$ [Accessed 27 Jun. 2019] 
IMF (International Monetary Fund), (2019). Fiscal Transparency Initiative: Integration of Natural Resource Management Issues. IMF Policy Papers [online]. Imf.org. Available at: https://www.imf.org/en/Publications/Policy-Papers/Issues/2019/01/29/pp122818fiscaltransparency-initiative-integration-of-natural-resource-management-issues [Accessed 25 Jul. 2019]

Lakin, J., and de Renzio, P. (2019). Reframing Public Finance, Promoting Justice, Democracy, and Human Rights in Government Budgets [online]. Available at: https://www.internationalbudget.org/wp-content/uploads/reframing-public-financejustice-democracy-human-rights-in-government-budgets-ibp-2019.pdf [Accessed 3 Jul. 2019]

Löfgren, K.G., Persson, T., and Weibull, J.W. (2002). Markets with Asymmetric Information: The Contributions of George Akerlof, Michael Spence and Joseph Stiglitz. The Scandinavian Journal of Economics, 104(2), pp. 195-211. https://doi.org/10.1111/1467-9442.00280

Nash, J. (1951). Non-Cooperative Games. Annals of Mathematics, 54(2), pp. 286-295. https://doi.org/10.2307/1969529

Nash, J. (1953). Two-Person Cooperative Games. Econometrica, 21(1), pp. 128-140. https://doi.org/10.2307/1906951

Plott, R., and Smith, V. (1978). An Experimental Examination of Two Exchange Institutions. The Review of Economic Studies, 45(1), pp. 133-153. https://doi.org/10.2307/2297090

Rusiciano, F.L. (1990). The Prisoners` Dilemma as an Extended Arrow Problem. The Western Political Quarterly, 43(3), pp. 495-510. https://doi.org/10.2307/448701

Smith, V. (1991). Rational Choice: The Contrast between Economics and Psychology. Journal of Political Economy, 99(4), pp. 877-897. https://doi.org/10.1086/261782

Smith, V. (1994). Economics in the Laboratory. The Journal of Economic Perspectives, 8(1), pp. 113-131. https://doi.org/10.1257/jep.8.1.113

Szarovská, I. (2016). Quality of Public Finance and Economic Growth in the Czech Republic. Acta Universitatis Agriculturae et Silviculturae Mendelianae Brunensis, 64(4), pp. 1373-1381. https:// doi.org/10.11118/actaun201664041373

Wessen, R.R., and Porter, D. (1998). Market-Based Approaches for Controlling Space Mission Costs: The Cassini Resource Exchange [online]. Available at: https://trs.jpl.nasa.gov/bitstream/handle/2014/19001/98-0158.pdf?sequence=1\& isAllowed=y [Accessed 13 Apr. 2019] 